\title{
French Feminism vs
}

\section{Anglo-American Feminism:}

\section{A Reconstruction}

\author{
Sylvie A. Gambaudo
}

UNIVERSITY OF DURHAM

\begin{abstract}
This article opens with the questioning of a now established scholarly category, 'French feminism'. It proposes that theoretical and polemical understandings of 'French feminism' have been founded on an opposition to its counterpart, 'Anglo-American feminism'. The measure of this opposition has been defined mostly as geographical, linguistic and cultural. But underneath such constructions often lies the old sameness vs difference debate that has captivated feminism since the suffragettes. The article argues for a less oppositional and less discounting definition of the two strands of feminism. It proposes to read oppositional classifications as motivation for a dialogue addressed to the 'other' of theoretical constructs; questioning the likelihood of foregoing oppositional classification.
\end{abstract}

KEY WORDS Anglo-American $\bullet$ difference $\bullet$ feminism $\bullet$ French $\bullet$ other (otherness)

Is there such a thing as 'French feminism'? Judging by the growing number of texts using the term, undoubtedly 'French feminism' has entered the annals of scholastic terminology. It has become a self-explanatory expression that the sentient recognize as a coded referent, signalling the users' inclusion in a certain way of thinking. It signals belonging and it signals an existing intellectual tradition. To conceive of French feminism as a 'tradition' implies that the term has gained momentum and recognition. Yet, this is far from a true representation if we consider the vehement and fertile exchanges that have gathered and opposed the so-called French feminists and their critics. A taster of such exchanges could go as follows. The French feminists' 'woman', excluded from masculine discourse, is at best the other of man's symbols. A nothing or a mystic figure, her language defies comprehension, and confirms her as the marginal and impotent of discourse.

European Journal of Women's Studies Copyright (C) 2007 SAGE Publications (Los Angeles, London, New Delhi and Singapore), 1350-5068 Vol. 14(2): 93-108; http:/ / ejw.sagepub.com DOI: 10.1177/1350506807075816 
Decidedly of western extraction, the French feminist 'woman' is locked in an either/or of 'the idealistic tendency of structuralist thought [ignoring] the historical/social specificity of language structures' (Nye, 1986: 51). The Anglo-American feminists' views on 'woman' are equally damning. Founded upon 'the American interest in the self; the British emphasis on class ... puritanical and work-oriented' (Stanford-Friedman, 1993: 249), the Anglo-American feminist 'woman' lacks originality. Her structure occasionally chimes with phallocentric and her style conveys a sense of deja vu. But, leaving the sometimes acerbic arguments on the back-seat, both sides agree on one thing: French feminism is not the sum of its parts, it is not French and it is not feminism. Yet, the term sticks above such terms as 'third wave feminism', 'post-feminism', 'post-structuralist feminist literary theory', etc. Even if they are not entirely equivalent, these terms are often interchangeable as they point to a different theoretical emphasis on something post, something past, something that comes after. After what? After the hard-core ideals of the feminist struggle. We would be dealing with the aftermath of feminism because, some believe, feminism is dead, feminism has reached its end and achieved its objectives. And yet, with front-page headlines such as 'Women now paid 30 percent less. Scandal as pay gap with men reaches a record 25-year high' (Daily Express, 1 June 2004), it does not take much ingenuity to perceive that even very early feminist equal opportunity objectives, which, by virtue of being quantifiable, may appear less complicated to carry through, are far from having been achieved. Moreover, with captions asking readers to phone-vote on 'Should women get same pay as men?' (Daily Express, 1 June 2004: 12), it appears that the very spirit of equal opportunity, elicited by suffragettes from the mid-1860s onwards, has still not been assimilated by some of our 21st-century constituents. So, while some claim feminism is passé, unsurprisingly, others claim feminism has failed to deliver the promised post-patriarchal land it announced. To evaluate such a bleak prognosis in such a short space would not do justice to the extraordinary revolution that feminism has been and still is. As a starting point, I now emphasize one aspect of feminist history (the sameness and difference debate) that strikes me as significant in understanding French feminist thought.

The first two waves of the feminist struggle are historically typified first by a call for the equal treatment of women with regards to civic and social rights and second by the recognition of women's right to difference. In the first instance, the claim to equality was founded upon a logic of sameness whereby since women are as rational as men, society carries a duty to give its female citizens equal opportunity to take part in social organization: education, suffrage, etc. Early feminists thus elicited the debate 'equality vs difference' that would from then on be at the core of feminist debates. Early views centred round the assimilation of woman to man, effectively encouraging woman to become like man in character (rational, proactive, 
responsible, etc.) while otherwise retaining her femininity (caring, maternal, supportive, etc.). But the assimilation of woman to man and the subservience of her feminine condition to the advancement of man soon became the target of criticism for a second wave of feminists who, thanks to the hard work of early feminists, were now educated, better represented in the workplace, in the political arena, etc. - in a word equipped to challenge the ideology of patriarchal organization.

Second-wave feminists rejected early feminists' bid for equality on the ground that equality effectively encouraged women to see themselves with a man's eyes. Equality could be gained on the condition that woman be gauged by the same criteria that defined man. In short, equal to man meant same as man. Outside this model, women were still denied visibility and recognition. Second-wave feminists defied the patriarchal status quo by declaring woman different. Different from what? Different from the woman she was as the counterpart of man, with different needs, different sensitivity, different modes of expression, etc. than those man had defined for her. These feminists efficiently theorized woman's situation. They proved that woman was used as the invisible thread that keeps the patriarchal social fabric together, and that this position was far from gratifying, let alone fulfilling her (Kate Millett, Betty Friedan, Germaine Greer, for instance). Discontented with such misrepresentation and mistreatment, woman would, from then on, do her own defining. To this effect, second-wave feminists used radical measures (hence 'radical feminism') and did a spectacular job in pulling this different woman out of her closet by giving her difference substance. A distinctly female authorship was salvaged from the scraps of mainstream literature and promoted as part of a historicizing of women's literary achievement (for instance, Virago Press). Women authors wrote more systematically about women's experience, making audible a consciousness that had previously been kept silent. The English language, construed as a man-made language (Dale Spender, 1980), became a terrain of investigation of women's oppression and some (Suzette Haden-Elgin) suggested that the creation of a language to accommodate specific female experience would change women's lives (this idea survives in policies of political correctness).

However, as radical feminism progressed, so did the formalization of the difference debate, pitching opposing theoretical factions against each other. Disputes among feminists show that although the move to promoting women's difference was animated by a genuine desire to create a sisterhood where women might find legitimacy, this sisterhood was itself struggling to unify the desires of all its members. Initially steered by white, middle-class, heterosexual women, issues of class, race, sexuality, etc. divided the movement and subgroups emerged to account for those differences, for instance black feminism, lesbian feminism, etc. These subgroups testified to the dissatisfaction with the assimilation of woman to 
her 'difference' because assimilation also homogenized all women to a 'sameness in difference'. Hence, the initial dissatisfaction with the assimilation of woman to the dominant discourse and with her subservience to the advancement of that dominant group was disappointingly repeated within the movement.

The argument for the failure or even end of feminism usually refers to this turbulent time of internal disagreements. Yet, the issue of sameness/ difference, far from being dead or passé, would go through further theoretical phases where men and women would be scrutinized for biological, psychological, behavioural, environmental similarities and differences that would justify (or refute), explain (or confuse), the existence of the categories man and woman. As the formalization of the sameness/difference continued, so new schools of feminist thought were created. It is a tribute to the movement that the division of opinion and the splintering of 'feminism' into what could be called feminist 'specialism' has not translated into the demise of feminism but its transformation and diversification. However, the increased formalization and specialization of feminist thought has also intellectualized the debate and made its former bra-burning, slogan-brandishing presence less pronounced. In a culture where visibility often rhymes with media spectacle, the perception that feminism is passé is also to be attributed to its discretion. Finally, it seems to me that the perception that militant feminism has 'disappeared' from the social arena is due to the redistribution of many of its causes in nonfeminist identified areas of social reform. Equal opportunity, political correctness, diversity awareness, parity, etc. are today's catch-phrases that hide behind them the continuation of contemporary feminist militantism.

Third-wave feminism takes its place in this context of increased intellectualization of the debate. The debate over sameness/difference has moved away from confrontational means of gaining social reform and towards a more academic style. Third-wave feminists are invested in articulating theories explaining why, in spite of the work done, the debate persists and how to transcend it.

Alice Jardine (1982) and Toril Moi (1988) are largely responsible for the use of the term 'French feminism', the one for the coining of the term and the other for further limiting its use to a few selected authors. In her famous article, 'Gynesis', Jardine detected the emergence of French feminist thought out of the intellectual scene of 1980s France. Characterized by the dawn of what has been termed 'modernity' or 'postmodernism', French theorists were invested in theorizing the failure of the modernist project and moving its failed dialectic towards new theoretical horizons. For the feminist project, this translated in revisiting the debate over sameness and difference. As for Toril Moi, the publication of her Sexual/Textual Politics in 1985 made official a division between Anglo-American feminists and French feminists. Anglo-American feminists (Kate Millett, Virginia Woolf, Elaine Showalter) would be invested in seeking a woman-centred 
perspective and in defining a woman identity they believe women have been denied. French feminists (Hélène Cixous, Luce Irigaray, Julia Kristeva), on the other hand, would be indebted to Simone de Beauvoir and would believe that woman does not have an identity as such but that the feminine can be identified where difference and otherness are found. Today, the term French feminism is commonly used in Anglo-American literary circles. It is this packaging of the adoption of the term 'French feminism' and how it contributes to the sameness/difference debate that this article now addresses.

Most researchers (Delphy, Lechte, Smith, Moi, etc.) concur on the idea that French feminism is an Anglo-American invention. They argue that its purpose is to commodify, behind the qualifier 'French', this evanescent part of continental thought for domestic consumption.

Geographical fencing off (identifying separate French and AngloAmerican feminisms) would be a metaphorical fencing off of two distinct ideologies. On the one hand, Anglo-American feminism denotes a geographical limit. More than this, 'Anglo-American' pertains to a linguistic tradition that does not seem to concern 'French'. The US and the UK share, since the Reagan/Thatcher years, this 'special relationship' that transcends a mere common language. 'French' thought, on the other hand, does not necessarily include French-speaking countries other than France and certainly does not imply the grouping of two or more national territories according to linguistic and political privileging. A famous example is found in Moi, who defines as the 'Holy trinity' of French feminist theory three women (Irigaray, Kristeva, Cixous) who are respectively Belgian, Bulgarian and French pied noir. If French feminism does not necessarily include French natives, it does include thinkers of a common intellectual tradition. But this common intellectual tradition is defined from without. French feminism is 'a body of comments by Anglo-American writers on a selection of French and non-French writers: Lacan, Freud, Kristeva, Cixous, Derrida and Irigaray are the core groups. But there are others' (Delphy, 2000: 172). Though not all of them French, and leaving Freud aside for now, they do have in common the French language as their elected mode of expression. This may not simply be intellectual arrogance, reserving French thought for the conversants into the riddles of the continental post-structuralist linguistic games. Kristeva expressed this clearly when she stated that 'Foreigners must confront a ghost from the past that remains hidden in a secret part of themselves' (Guberman, 1996: 4). In choosing to express themselves in a foreign language, these theorists are also giving themselves a tool to tap into archaic contents of the subject's being.

Kristeva also stresses that we all carry memories of childhood connected with places, their colours, smells and sounds, and that the reason for which these recollections are often hazy is that we find it difficult to express them 
in words: as adults, we have lost touch with the language of childhood. A foreign language can help us translate those early impressions of the world into words because it is more distanced from them than our mother tongue is. It is for this reason that Kristeva found her analysis, which was conducted in French, helpful in transposing her images of childhood onto her new culture. (Cavallero, 2003: 144-5)

Indeed, the distance French provides to these 'foreign' French feminists enables them to deal with and represent pre-oedipal contents. But protection through linguistic distancing is not the sole motivation for gathering around the French language. Connections between the language and other issues like translation, otherness and oppression are embedded in the language. 'Foreign' French feminists and Anglo-American critics' absorption in French bears significance even more visibly when their choice to read or speak French is not the fortuitous consequence of having been brought up into a language. It is interesting to pause on the history of the French language and specifically on its long-lived association with power struggles, won and lost. I am not suggesting that such an association is the appanage of French since linguistic imperialism has long been a recognized weapon of colonization and submission of the one culture by the other. But I am emphasizing the fact that France and the French language have a long history as linguistic oppressor and oppressed and that this implicit history is also part of the lure to French of a certain intellectual practice.

The use of the French language was first made compulsory by Hugues Capet (10th century) as part of the government's effort to absorb southern provinces to the Duchy of Paris. The langue d'oil, the dialect of Paris then became the official language, effectively causing the demise of languages spoken south of the Loire river until their revival in the mid-19th century in an attempt to assert a regional Occitan identity (Provençal, Catalan, for instance). While 'minor' languages have been restored, the government is at the same time fighting for the survival of the French language in France, in a globalizing context where linguistic supremacy is driven by the market economy. I am thinking of the Toubon Law for instance, which imposes the compulsory but not exclusive use of French on certain documents (consumer goods, instruction manuals, advertisements). The Body Shop was famously the first company to be fined in 1996 for failing to comply with the Toubon linguistic rule. So the French language has historically oscillated between weapon and recipient of linguistic oppression. We may further hypothesize that more recent sociopolitical events help explain why the French linguistic context may be prosperous to a certain type of thought.

French has become one of the languages to express ideas of difference par excellence. The claim for France's position as the champion of 'difference' was initiated under the Mitterrand government. But the idea arches back to the French Revolution. The year 1789 is seen as the turning point, 
when a change of focus is observed in philosophy, literature, politics, etc. Eighteenth-century values had failed to bring social happiness and ended in bloodshed. Social and political unrest, rapid technological advances, the rejection of rationality in favour of emotions, etc., translated in a move away from collective concerns to that of the individual and his/her singularity. Hence, the use of French as the language of predilection by theorists of French thought (not necessarily French themselves) is no coincidence.

If France sponsors a tradition of difference, the clash between French and Anglo-American thinkers is not surprising. Could the use of the French language also be a defensive linguistic response against the feared American linguistic imperialism trading even closer by virtue of the British alliance with the cultural giant? If there is a withering away of language, as Kristeva proposed, and of the French language and culture in particular, one response 'consists in turning back toward tradition in a loving, proud, reactive, nostalgic fashion' (Guberman, 1996: 169). Another, as I explained elsewhere, ${ }^{1}$ privileges the subversion of text over protectionist measures. French feminism, feminism in French then, is a reactive and subversive response. French feminist strategy is not as apolitical as many Anglo-American feminists would have it. Its sociopolitical engagement can be extrapolated from this: the use of a receding language is the means by which French feminists destabilize, escape the grip of dominant ideology and ultimately coerce this dominant ideology to reckon with issues of marginalization. The irritation of Anglo-American feminists is understandable. But in the battle for linguistic authority, so is the irritation of French feminists at the Anglo-American label. For reactive and subversive strategies go beyond a mere attack on geographical and linguistic imperialism. Issues of national or linguistic dominance should be read as the symptom of a much wider problematic that interests French feminists: that of representation, or more precisely, re-presentation as the secondary presentation of a primary process. This leads us to the issue of translation and we can now return to the place given to Freud in French feminist theory and make a few remarks on his contribution.

Freud's position has prime significance in the context of French feminism and pre-oedipality. Freud historically precedes all other French feminist thinkers. Freud acts as a referent. Freud is the link to a shared fascination for a certain conception of consciousness that can be traced back to his tradition. French feminism is also post-Freudian feminism. The Anglo-American readership of a post-Millettian persuasion is undoubtedly suspicious if not averse to such acceptance of the paternalist enemy. ${ }^{2}$ This is in some ways justified, but also partly a misreading of those French feminists. In theorizing representation of the individual, French feminist thinkers have in common their interest in pre-oedipality. Representation of the maternal experience typifies French feminism. It also draws them apart. From the search for a specifically feminine mode 
of representation to the protective holding on to the symbolic as the ticket to safety, French feminist narratives tell of a questioning addressed to the paternal and to the maternal. From subversive to reactive then, French feminist representation oscillates between dissidence from and compliance with the patriarchal letter.

To the dismay of Anglo-American feminists, dissidence is not spelt out in the narrative. Dissidence is in the confusion and ambiguity of expression and must be extrapolated. We are in the grips of translation on several levels. First, to express oneself in a foreign language in to speak another language. The leap from foreign languages as the language of the others, to foreign language as the language of foreignness or otherness is easily made. Hence, a first meaning of translation is found in this Freudian reading: leap from other to proper self, from pre-oedipal to symbolic, from maternal to paternal, etc. Second, the confusion or ambiguity present in the French text leaves the English translator with the ungrateful task of making choices: fixing the other, the pre-oedipal, the maternal with linguistic symbols (interpreting while translating); translating the ambiguity with the use of slash symbols (for example féminin becomes feminine/female); rewriting the text in English and using the ambiguity of the English language to make a point (Nicole Ward-Jouve does this, for instance).

That translation dissolves, alters and reforms meanings is nothing new. But the agency of translation (or of the translator) perhaps has not been emphasized enough. 'One cannot ignore issues of translation and cultural difference in the representation of a writer's thought', Smith (1998: 5) exclaims. Indeed, translation demands that we address these two aspects of its practice. French feminists are attached to the French language as the privileged space where they construct meaning. This is significant, as we have seen earlier. English translators distort that construction and, with or without their approval, impose an Anglo-American identity upon French feminists. There is a tendency to assume the equivalence of the French and English languages, equalling their differences to a kind of transcendental reality of meaning, a transcendence both languages would be subject to. At times, this has led to aberrant interpretations founded, not so much on a poignant analysis of text, but on the indiscriminate analysis of the translated text. I am regularly reminded of this difficulty when perplexed students attempt the perilous task of making sense of 'the feminine'. There is feminine (a sociopolitical reality) and there is feminine (a positioning of identity). In fact, both meanings are diametrically opposed. From a feminist perspective, the sociopolitical feminine is on the side of patriarchal representation of 'woman' while the 'positioned' feminine is on the side of the non-verbal, or the transverbal, if we are lucky. In Lacan's infamous 'woman is not', the metaphoric woman is in the void, absence, invisibility, the in-between of language. The sexism of such a remark is not in the suggestion that under patriarchal analogy women do not exist 
symbolically but in arresting thought at that. Luckily, authors like Cixous rescue the Lacanian sentence by showing the possibility to create those in-betweens as literary practice. Although woman is still absent or invisible, she is now intentionally created. So language, once decried as 'man-made' (Spender) can now be effected, against Lacan, to 'make woman'.

The difficulty with such a practice is to work on two opposite registers at once. When Hélène Cixous writes of écriture féminine or of the other bisexuality, she works on two levels: a literal level and a metaphorical level. Susan Sellers sums it up: 'we all continually fluctuate between gender roles, sometimes assuming defensive, "masculine" positions, at other times willing to risk prohibition, and at other times combining elements of each' (Sellers, 1994: xxviii). Yet, Sellers' statement is still too organized, too phallogocentric, too much of a remark founded on the differentiation of meaning whereby, although we are offered three terms, one is either masculine or feminine or a combination. Cixous' expression is an either/ or and all of those at once. It expresses at the same time meaning as the outcome of differentiation and meaning as the non-exclusion of difference' (Cixous, cited in Sellers, 1994: 41). Freud taught us that difference is founded on exclusion and that the excluded must be the mother. Cixous emphasizes another difference, difference without exclusion, difference before exclusion:

I will never say often enough that the difference is not one, that there is never one without the other, and that the charm of difference (beginning with sexual difference) is that it passes. It crosses through us, like a goddess. We cannot capture it. It makes us teeter with emotion. It is in this living agitation that there is always room for you in me, your presence and your place. I is never an individual. I is haunted. I is always. Before knowing anything, an I-love-you. (Cixous, cited in Sellers, 1994: xviii)

The other bisexuality is both the reunion after castration of the two halves elicited by $\mathrm{Ovid}^{3}$ and 'the location within oneself of the presence of both sexes' (Cixous, cited in Sellers, 1994: 41) before sexual difference, before the knowledge that one can be cut. So, écriture féminine is: an essentialist idea for which only those endowed with a female body have the potential; a socially determined idea whereby femininity is a reconstructed psychical positioning open to all; both at once.

It seems, then, puzzling that from a desire to 'inscribe difference at the heart of the universal' (Kristeva, cited in Guberman, 1996: 269), French feminists are regularly accused of essentialism. This is especially true of Kristeva, whose attachment to the oedipal model has alarmed feminists, raised suspicion as to her motivations and provoked virulent responses to her message. Her strategy is always to rehabilitate the shattered subject of the 'crumbling social contract' (Kristeva, 1974: 224) through the 'search for [its] legitimisation through the paternal function' (Kristeva, 1974: 224). 
Does this entail the betrayal of the feminist cause? For the legitimization of the social subject necessarily means the repression of the feminine. Kristeva has defended herself, accusing Anglo-American feminist theorists in particular of perpetrating 'unconsciously the very oppositions they are trying to undo' (Kristeva, cited in Guberman, 1996: 107):

I believe that much of what has been written in the United States about my conception has been inaccurate. People have either defined and glorified the 'semiotic' as if it were a female essence or else claimed that I do not grant enough autonomy to this 'essence', this 'difference'. I hear in such reductive statements traces of the age-old debate between 'universalists' and the 'differentialists'. (Kristeva, cited in Guberman, 1996: 269)

The attack on liberal (universalist) and radical (differentialist) feminists is explicit and understandable. The trapping of Kristevan thought into an either/or dialectic makes it difficult to rescue the Kristevan project, unless we reconsider it from the perspective suggested by Cixous of difference before exclusion. We find it explicitly in Kristeva also, under the guise of the 'maternal function' or the 'woman effect':

... it entails a specific relationship to both power and language or, if you will, to the power of language. This particular relationship is based not on appropriating power and language, but on being a source of silent support, a useful backdrop, and an invisible intermediary. (Kristeva, cited in Guberman, 1996: 104)

Silent, supportive, useful, invisible, in-between ... This is hardly a glorifying image of women's social role. But Kristeva is not simply talking about biological women. 'Maternal' and 'woman' refer, as in Cixous, to a time anterior to paternal castration, a moment when antinomic worlds can coexist without shattering one another. This is an experience the future subject internalizes and of which the presence will make itself felt in a certain type of expression: poiesis, écriture féminine, etc. What hinders the assimilation of such terminology is the confusion between two registers pertaining to two experiences: that of the presocietal and that of social organization. The capture of 'maternal' or 'feminine' in and as the body of woman is a 'symbolic effect of the way the subject experiences social cohesiveness, power and language' (Kristeva, cited in Guberman, 1996: 104). It is the way society requires we organize ourselves as social members. For the French feminist, destroying the patriarchal markers of such a passage from presocial to social does not fundamentally change the problem. We may choose to discard the lipstick or cultivate a revolutionary Greenham Common style image for 'woman', this still points to a symbolic evocation of 'woman'. The Anglo-American feminists' frustration with French feminism can also be located here. If French feminists succeed in demolishing 
all social action by reducing it to a 'symbolic effect' of something other, what is the alternative? Does the 'interiorisation of the founding separation of the sociosymbolic contract' (Kristeva, cited in Belsey and Moore, 1990: 215) offer feminism any hope?

My initial argument that the (mis)understanding of 'French feminism' is a translation issue has, then, slipped sideways. French thought is now an obstruction to capturing the picture. French feminists are in the habit of holding antithetic propositions under one thesis. This does not easily pass the translation barrier from the French to the English language. Translators of French feminist texts are time and time again faced with the difficult task of rendering the French feminist spirit: 'we have not made the effort to create a seamless, smooth American English text', one translator comments (Cixous, 1994: xxvi). Instead, the translator seeks 'to make the familiar uncanny' (evoking the Freudian Unheimlich [Freud, 2003]), 'the translation ought to aim at this sort of dépaysement' (Cixous, 1994: xxvi). Anne-Marie Smith (1998) and John Lechte (1991) have suggested that the difficult passage from French into English may be more of a cultural difficulty, indeed a dépaysement, than an actual translation barrier.

Smith proposes that Anglo-American thought demands of theory that it be testable:

Freud is certainly in a more comfortable position in France than in Britain or the United States, where in the wake of the recent vituperative indictment of Freud, written by the American intellectual Frederick Crews, the national, liberal press has entered into a trend which, setting psychoanalysis against the demands of empiricism, attempts to disprove its theories as non-scientific. The French Lacanian tradition reads Freud as a study of language. (Smith, 1998: 8)

The main difference between French and Anglo-American intellectual cultures comes down to a difference in the way the Freudian message has been received. Smith's packaging of Anglo-American psychoanalytic thought is in itself questionable in the light of the diversity of readings (I am thinking of the distinguished post-Kleinian British School of Object Relation Theory). John Lechte overcomes this when he observes that the cultural difference is not so much a French vs Anglo-American conflict but the stumbling upon a limitation in rational thought:

The limit of phenomenological research is that it always, and inevitably, refers back to an ultimate unity, a posited subject of experience, a Cartesian subject in fact which is already an ' $\mathrm{I}$ ', already the result of the distinction between subject and object. (Lechte, 1991: 134)

The divide pitches established frameworks of thought of a Cartesian persuasion against conceptions of the subject that exceed such frameworks. 
Although such persuasion partakes in the historical making that defines contemporary western thought, it certainly cannot be traced back to an Anglo-American cultural tradition. Rather, reading through Lechte, we are dealing with a historical clash of cultures pitching proponents of the modernist project against the less peremptory discourses of late and postmodernism. In this sense, the issue is not that Anglo-American theorists read Freud differently from French feminists but that they read Freud and French feminism with the same suspicion for their lack of a solid objective base. As Smith notes:

... there is an aspect of French cultural life in general which involves unabashed avowals of desire and seduction and distinct forms of identification which a puritanical streak in Anglo-American culture resists as narcissistic or uncritical and needs to turn into either abstractions or plain speech. (Smith, 1998: 8)

French feminism reiterates after Freud a message of estrangement from the motherland. This space of estrangement, of dépaysement then, is in fact what French feminists constantly flirt with and what Anglo-American culture defends itself against:

There is a staging of sensory pleasure which is not always considered politically correct, or critical, across the Channel or the Atlantic. This is a form of resistance which goes far beyond distinguishing the package from the product and in the name of critique translates itself as a refusal of seduction, and an obsessional defence against hysteria of foreignness and femininity. This sort of defensiveness is of course at the basis of any serious critical work but it is also a measure of cultural difference which is played out, I would argue, in relation to the question of seduction and resistance, just as xenophobia and misogyny are extreme examples of defences against the lure of foreignness or femininity. (Smith, 1998: 9)

Smith's statement clearly proposes a dualistic relationship between the two poles of feminist criticism, divided by a political or geographical barrier. Interestingly, her choice of geographical divide, the sea or ocean, fits the purpose of her message that it is something along the lines of the maternal, hysteria, foreignness, femininity, that separates the two. That this should be played out as a xenophobic singling-out of French feminism would entail, if we follow her lead, Anglo-American feminists' defence against the maternal, the feminine, etc. In other words, American critics would have invented 'French feminism' to express ideas unpalatable for American domestic consumption under the cover of 'foreign theory'.

If we go along with this, it would mean that Anglo-American feminists have become the oppressors, French feminists the oppressed. Are we then witnessing a repeat of feminist history with the old dialectic impossibility 
of accommodating difference within dominant discourse? All the ingredients are certainly here: the demands that discourses of difference (French feminism) be brought into line to comply with acceptable feminist discourse (Anglo-American feminism); the complaint from French feminists that Anglo-American feminists do not understand and oppress them; etc. But while their respective narratives reveal a clash in methods and objectives, there are also crucial concessions granted theoretically on both sides.

For psychoanalytically oriented French feminism, differentiation will be played out. Whether in sexism, racism, ageism, sexual orientation or any other group, the existence of exclusion remains. The erasure or modification of categories such as sex, race, age does not fundamentally change the outcome of exclusion, only the form it takes. Similarly, the suspension of the differentiation theory will not suspend difference and by extension exclusion, sexual or otherwise. If exclusion is not permitted in one area, it will simply displace onto another. It is a small leap for French feminists to concede that differentiation will also be played out in feminism, that the fabrication of difference and of exclusion will occur no matter the goodwill of (Anglo-American) discourse.

In the view of the mounting Anglo-American interest in the French feminist approach, especially with regards to their explanation of the psychical dynamics of exclusion that animate every individual (Cavallaro, 2003), the construction of Anglo-American feminism as the adversary of French feminism is not tenable. It is precisely their interest, which has permitted the dissemination of French feminist ideas beyond the circles of the Parisian elite. But if Anglo-American interest is not malevolent, it is not benevolent or gratuitous either. Spivak (1981) has shown that interest in the 'other' is rarely for the other's benefit but more egotistically to gain a better understanding of oneself. She says, 'in spite of their occasional interest in touching the other of the West, of metaphysics, of capitalism, their repeated question is obsessively self-centred: if we are not what official history and philosophy say we are, who then are we (not), how are we (not)?' (Spivak, 1981: 158-9). As post-structuralist theory has questioned the self-reflexive complacency of western history and philosophy, categories they sought to explain have also been questioned. The subject, capitalist social organization, etc. are being revisited, defended or vilified. But Spivak finds that this questioning remains a self-reflexive exercise rather than opening a dialogue with the other. The other's vision 'others me', voices the negative spaces of my being. So the discourse of the other provides me with a fuller picture of the 'hows' and 'whats' of my invisible being. If we apply Spivak's idea to the AngloAmerican/French debate, what interests Anglo-American critics, when it does not fascinate and anger them, is the space where French feminists deny Anglo-Americans an existence. Hence, one of the major appeals of 
and objections to French feminism is the manner in which it supports theories of difference and cherishes issues of otherness at the risk of idealizing the notion of 'Other'. For if the notional other loses its grounding in any given sociopolitical reality, which 'other' is being lost? The AngloAmerican objection to the creation of a utopian universalized Other would be an objection to being assimilated, as the other of French theory, to a theoretical construct lacking specificity and roots in social reality. French feminism would be inviting the dominant discourse to address issues of its own dissolution.

To conclude, it may not be that Anglo-American feminists created French feminism and then used it to voice, under the cover of 'foreign theory', concerns impertinent to the dominant Anglo-American discourse. But, it may well be that some Anglo-American feminists, who after a long battle had earned social, political and academic credence, suddenly found their secure base vulnerable to theories of difference. Then, we would be justified in thinking that the so-called dialogue that has opened between the two types of feminisms remains for many Anglo-American theorists a tool for self-study rather than an opportunity to address the notion of otherness. I would, however, propose to question this dreary conclusion and finish on a more positive note.

French and Anglo-American feminisms cannot be reduced to geographical, cultural or linguistic denotations. In effect, I hope to have demonstrated that they cannot be identified in isolation. From a political viewpoint, it seems that both sides are engaged in a power play at who-will-dissolve-theother. French feminism is inviting Anglo-American feminists to revisit their comfortable position and Anglo-American feminism is teasing clarification out of French feminists' seductive linguistic enigmas. This article has mostly emphasized the unsettling effect French feminism has on AngloAmerican feminism, or rather the manner in which French feminism is construed as that which upsets the Anglo-American feminist edifice. The reverse could also have been argued. By placing itself as the other of otherness, Anglo-American feminism is positing itself as guardian of the symbol, be it a feminist symbol - a somewhat ironic outcome. It would be equally interesting to analyse how much Anglo-American feminism has reinforced the inclination of French feminist discourse towards incarnating the discourse of otherness. By isolating and assuming the existence of French feminist discourse, by adopting a sanctioning tone - feminist discourse must have a clear political agenda, must not be essentialist, etc. - AngloAmerican feminism has, undoubtedly, ignited and fuelled a debate. A less prohibitive and more inclusive analysis would conclude that the constant crossing of the divide that separates these two particular poles of feminist criticism has revived western feminism, offering fertile exchanges and novel conceptions of subjectivity and gender. 


\section{NOTES}

My thanks go to Jennie Finch for her help.

1. In Fendler and Wittlinger (1999).

2. I am thinking about Kate Millett's seminal text Sexual Politics (specifically 'Freud and the Influence of Psychoanalytic Thought' and 'Some PostFreudians'), which fiercely exposed the sexism of the Freudian edifice (Millett, 1977). Although Millett was not the only one to denounce Freud, her work stands as representative of that which prompted a wave of discontent that would typify radical feminism in particular. But separatism was not the only effect this consciousness raising had. Other feminists chose to revise the Freudian account (Juliet Mitchell, Jaqueline Rose, Sarah Kofman and Janine Chasseguet-Smirgel, for instance), thus creating the third wave of the feminist struggle.

3. 'Salmacis and Hermaphroditus' in Ovid's (1968) Metamorphoses.

\section{REFERENCES}

Belsey, Catherine and Jane Moore, eds (1990) The Feminist Reader: Essays in Gender and the Politics of Literary Criticism. London: Macmillan.

Cavallaro, Dani (2003) French Feminist Theory. London and New York: Continuum.

Cixous, Hélène (1994) The Terrible but Unfinished Story of Norodom Shanouk, King of Cambodia. Lincoln and London: University of Nebraska Press.

Delphy, Christine (2000) 'The Invention of French Feminism: An Essentialist Move', Yale French Studies No. 97, '50 Years of Yale French Studies: A Commemorative Anthology, Part 2: 1980-1998': 166-97.

Fendler, Susanne and Ruth Wittlinger, eds (1999) The Idea of Europe in Literature. London: Macmillan.

Freud, Sigmund (2003) The Uncanny. London: Penguin.

Guberman, Ross Mitchell (1996) Julia Kristeva: Interviews. New York: Columbia University Press.

Jardine, Alice (1982) 'Gynesis', Diacritics 12(2): 54-65.

Kristeva, Julia (1974) Des Chinoises. Paris: Editions des Femmes.

Lechte, John (1991) Julia Kristeva. London and New York: Routledge.

Millett, Kate (1977) Sexual Politics. London: Virago Press.

Moi, Toril (1988) Sexual/Textual Politics. London and New York: Routledge.

Nye, Andrea (1986) 'French Feminism and Philosophy of Language', Noûs 20(1), APA Central Division Meetings, March: 45-51.

Ovid (1968) Metamorphoses. London: Penguin.

Sellers, Susan, ed. (1994) The Hélène Cixous Reader. London and New York: Routledge.

Smith, Anne-Marie (1998) Julia Kristeva: Speaking the Unspeakable. London and Sterling, VA: Pluto Press.

Spender, Dale (1980) Man Made Language. London: Pandora.

Spivak, Gayatri Chakravorty (1991) 'French Feminism in an International Frame', Yale French Studies No. 62, 'Feminist Readings: French Texts/American Contexts': 154-84.

Stanford-Friedman, Susan (1993) 'Relational Epistemology and the Question of Anglo-American Feminist Criticism', Tulsa Studies in Women's Literature 12(2): 247-61. 
Sylvie Gambaudo lectures in philosophy at the University of Durham. Her research focuses on psychoanalytic theory, feminist philosophy and the work of Julia Kristeva. She has contributed to the edited collections The Idea of Europe in Literature (Macmillan, 1999), Women in Contemporary Culture: Roles and Identities in France and Spain (Intellect, 2000), and is the author of the forthcoming Kristeva, Psychoanalysis and Culture (Ashgate, 2007). Address: University of Durham, Department of Philosophy, 50 Old Elvet, DH1 3HN, UK. [email: sylvie.gambaudo@durham.ac.uk] 